\title{
GÜÇ UNSURLARI İLE PAY SENEDİ GETİIILERİ ARASINDAKİ İLIŞKİ: OLAY ÇALIŞMASI (EVENT STUDY)
}

\author{
Dr. Öğr. Üyesi İstemi ÇÖMLEKÇİ \\ Düzce Üniversitesi, İşletme Fakültesi, (istemicomlekci@duzce.edu.tr) \\ Dr. Öğr. Üyesi Özkan ŞAHIN \\ Düzce Üniversitesi, İşletme Fakültesi,(ozkansahin@duzce.edu.tr)
}

\begin{abstract}
ÖZET
Bu çalışmada coğrafi konumu, ekonomik ve siyasi istikrart sonucu bölgesel ve uluslararası alandaki güç unsurları arasında yer alan Türkiye'nin finansal piyasalarının etkinliğinin test edilmesi amaçlanmıştır. Türkiye'nin ekonomik ve finansal gücü, askeri, siyasi ve ekonomik güç unsurları çerçevesinde olay analizi yöntemi ile incelenmiştir. Gücün, askeri, siyasi ve ekonomik unsurları çerçevesinde Türkiye'de son yillarda meydana gelen önemli olaylardan askeri olay olarak; 15 Temmuz Darbe Girişimi ve Fırat Kalkanı Harekâtı, ekonomik olay olarak; Rusya'nın Türkiye'ye Uyguladığı Ekonomik Yaptırımlar ve Varlık Fonunun Oluşturulması, siyasi olay olarak; Anayasa Değişikliği Referandumu ve ABD Vize Krizi ele alınmıştır. Çalışmada olay penceresi olarak $(t+10, t-10)$ dönemi alınmıştır. Çalışma sonucunda, $(-10,+10)$ olay penceresinde, darbe girişimi ve vize krizi olaylart için hesaplanan kümülatif normalüstü getirilerin sıfirdan farksız olduğu sonucuna ulaşılmıştır. Fırat Kalkanı Harekâtı, Ekonomik Yaptırımlar, Varlık Fonu ve Anayasa De ğişikliği Referandumu olayları ele

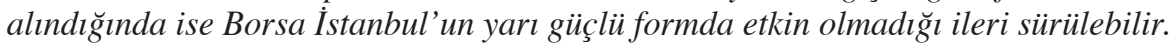

Anahtar Kelimeler: Olay Analizi, Güç Unsurları, Normalüstü Getiri.

\section{THE RELATION BETWEEN POWER ELEMENTS AND STOCK RETURNS: EVENT STUDY}

\begin{abstract}
In this study, Turkey's, which is become the regional and internatinol power with it's geographical location, economic and political stability, financial markets effectiveness testing was aimed. Turkey's economic and financial power has been examined by event study analysis method within the context of military, political and economic power elements. On the basis of military, political and economic elements of the force, major events that has been occured in the recent years as military event; 15th July military coup attempt and Firat Shield Operation, as an economic event; Russia's Economic Enforcement againts Turkey and Establishing of Wealth Fund, as a political event; Constitutional Referendum and US Visa Crises was taken into account. In the study, the period $(t+10, t-10)$ was taken as the event window. At the end of the study, the cumulative abnormal returns for the events of the coup attempt and the visa crisis at the $(-10,+10)$ event window were found to be zero. It can be argued that Stock Exchange Istanbul is not active in semi-strong form when the events of Firat Kalkan Operation, Economic Enforcements, Wealth Fund and Constitutional Referendum are taken into consideration.
\end{abstract}

Keywords: Event Analysis, Power Elements, Abnormal Return.

www.ijmeb.org ISSN:2147-9208 E-ISSN:2147-9194

http://dx.doi.org/10.17130/ijmeb.2019149858

Başvuru Tarihi: 09.03.2018, Yayına Kabul Tarihi: 07.09.2018

46
ORCID ID:

İstemi ÇÖMLEKÇİ 0000-0001-8922-071X

Özkan ŞAHIN 0000-0001-5341-1274 


\section{Giriş}

Finans piyasalarının gelişmesi bu piyasalarda yaşanan sorunların artmasını beraberinde getirmiştir. Bu sorunları sebepleri ve şiddetleri farklı olmakla beraber finansal kriz olarak nitelendirilebilirler. Finansal krizler piyasaları etkilemekle kalmayıp kısa zamanda reel sektörü de etkisi altına almaktadır.

Finansal krizler birçok ülkenin gelişmesinde ciddi bir yavaşlamaya neden olmaktadır. Hükümetler krizden güçlü bir şekilde çıkmanın yollarını ararken, küresel ekonomik faaliyetlere ilişkin önde gelen göstergeler endişe verici oranlarda azalmaktadır (Velde, 2008). Türkiye'de 1995 ve 2001 krizlerinin ekonomik ve finansal piyasalara yönelik olumsuz etkileri, alınan tedbirler ile giderilmeye çalışılmıştır. Bu krizlerden tarihten sonra oluşabilecek yeni bir krize karşın söz konusu piyasaları güçlü kılmak adına gerçekleştirilen reformlar, Türkiye'nin ekonomik ve finansal yapısını daha güçlü ve dirençli hale getirmiştir. Türkiye, yaşadığı krizler sonrası aldığı tedbirlere ve gerçekleştirdiği reformlara yönelik ilk büyük sınavını 2008 küresel krizi karşısında vermiştir. Özellikle 2001 finansal krizi sonrası bankacılık sektöründe gerçekleştirdiği reformlar ile bankacılık sektöründe köklü değişiklikler yapan Türkiye, yaptığ 1 bu reformlar ve iyileştirmeler sayesinde 2008 küresel krizinden en az etkilenen piyasalardan biri olmayı başarmıştır. Fakat bir ekonominin güçlü olarak adlandırılabilmesi için bu ve benzeri krizlerden genel olarak etkilenmeden veya en az derecede etkilenerek çıkabilmesi gerekmektedir.

Finansal anlamda güçlü olmak, sadece ilgili alanlardaki reformları ve iyileştirmeleri gerçekleştirmekle kalmayıp bunun devamlılığının da sağlanmasını gerektirmektedir. Bu noktada güç kavramının içeriği önem kazanmaktadır. Güç kavramının tanımı konusunda henüz bir fikir birliğine varılamamakla birlikte çeşitli araştırmacılar farklı şekillerde güç kavramını tanımlamışlardır. Robert Dahl'e (1957: 202-203) göre güç, bir kişi veya kurumun başka türlü yapmayacağı şeyleri başka bir kurum veya kişiye yaptırabilme kapasitesine denmektedir. Lukes'a (1974: 32-33) göre ise güç, bir kurum veya kişinin bir başka kurum veya kişinin davranışlarını kendi çıkarlarına ters gelecek şekilde yönlendirmesidir. Diğer bir ifadeyle kendi çıkarlarına ters olması pahasına bir başka aktörün etkisinde kalarak hareket ediliyorsa bu durumda bir güç kullanımından ve güçten bahsedilebilmektedir.

Sağlam'a göre (2014: 4-5) gücün en önemli bileşenlerinden maddi güç kavramı altında endüstriyel gelişme ve askeri güç olmak üzere iki alt bileşenden söz edilmektedir. Bir ülkenin ekonomisi, dünya politikasını etkilemesinde oldukça önemli bir faktör olan endüstriyel gelişme, bir devletin ekonomik büyüklüğü ve performansının göstergesi olarak gayrisafi millî hasılası ile ölçülmektedir. Aynı zamanda ekonomik büyüme, sermayenin kullanımı ve doğal kaynaklara ulaşılabilirlikle ilgilidir. Öte yandan merkezi bir gösterge olan askerî güç ise devlet gücünün can alıcı bileşenidir. Büyük orduya sahip olmak millî gücün hesaplanması için önemlidir. Çin, Rusya ve ABD'nin silahlı ordu nüfusu oldukça fazladır. Ama diğer taraftan, askerî gücü tamamen dışarıda bırakarak sadece GSMH, büyüme hızı ve dış ticaret hacmi gibi ekonomik verilere bakılarak da güç hesaplaması yapmak mümkün değildir. Bir devletin salt ekonomik gücünü öne çıkararak bölgesel ve küresel hedeflerine ulaşmasına imkân bulunmamaktadır (Erhan, 2012). 
Tanıma ilişkin ikinci zorluk, gücün zaman ve sistemik ilişkilerin yapısına göre değişken nitelik ve içeriğinden kaynaklanmaktadır. Örneğin, uluslararası hukuk kurallarının ve iletişim teknolojilerinin bugünkü kadar gelişmediği dönemlerde askeri unsurlar gücün ana içeriğini oluştururken, bugün diplomasinin kalitesine ek olarak bilgi kaynakları ve iletişim süreçleri üzerindeki kontrol, gücün temel niteliğini oluşturmaktadır. Küreselleşmeyle birlikte ekonomik ilişkilerin ön plana çıkması, askeri güç ve resmi ilişkilerin ağırlığını kaybetmesine, onların yerine ekonomik unsurlar ve devlet-dışı aktörlerin ön plana çıkmasına neden olmaktadır (Nye, 1990: 156-157; Barber, 1996: 23-34). Ekonomik unsurların ön plana çıkmasıyla birlikte, örneğin hiçbir ülkeye bağlılık hissetmeyen çok-uluslu şirketlerin gücünün de tanımlamalara dahil edilmesi gerekmektedir. Dolayısıyla zaman içerisinde uluslararası ilişkiler gibi, güç kavramı da evrim geçirmekte, onu tanımlayan unsurlar değişmektedir.

Hiç şüphesiz askeri güç, ekonomik güçle desteklenmedikçe ya da ekonomik çıkarlar askeri güçle korunamadıkça, ne askeri ne de ekonomik güç tek başına bir anlam ifade eder. Gücün bir diğer tanımı ise milli güç kavramı ile ifade edilmektedir. Türkiye Cumhuriyeti Milli Güvenlik Kurulu'na göre Milli Güç; siyasi, askerî, ekonomik, nüfus (demografik), coğrafi, bilimsel ve teknolojik, psiko-sosyal ve kültürel güçten meydana gelir (MGK, 2018). Tanımlardan da anlaşılacağı üzere güç kavramının tanımı konusunda kesin bir yargıya varmak zor olmakla birlikte gücün unsurları olarak üç temel bileşen belirtilebilir. Bunlar; askeri güç, siyasi güç ve ekonomik güçtür.

Bu kapsamda, bu çalışma ile Türkiye'nin ekonomik ve finansal gücü, gücün unsurları olan askeri, siyasi ve ekonomik olaylar çerçevesinde analiz edilecektir. Analiz için kullanılacak yöntem Olay Analizi (Event Study) yöntemidir. Olay analizi yöntemi piyasaları etkileyen ekonomik, siyasi, askeri, kültürel, afet vb. olayların pay senedi getirilerinde meydana getirdiği değişmeyi incelemede de kullanılan bir yöntemdir. Böylece ele alınan olayın ekonomik ve finansal piyasaları ne derece etkilediği belirlenerek literatürde Etkin Piyasalar Hipotezi olarak bilinen ve piyasaların etkinlik derecesini gösteren hipotezin de sınanması gerçekleştirilecektir. $\mathrm{Bu}$ çerçevede, Türkiye ekonomik ve finansal piyasalarının gücü ve etkinliği, etkin piyasalar hipotezi ve güç unsurları kriterleri ile Olay Analizi kapsamında analiz edilecektir. Gücün askeri, siyasi ve ekonomik unsurları çerçevesinde Türkiye'de son yıllarda meydana gelen önemli olaylardan askeri olay olarak; 15 Temmuz Darbe Girişimi ve Fırat Kalkanı Harekâtı, ekonomik olay olarak; Rusya'nın Türkiye'ye Uyguladığı Ekonomik Yaptırımlar ve Varlık Fonunun Oluşturulması, siyasi olay olarak; Anayasa Değişikliği Referandumu ve ABD Vize Krizi ele alınmıştır.

\section{Literatür}

Firma içinde veya paydaş ilişkilerinde meydana gelen ekonomik, politik, siyasi vb. olaylar ile pay senedi getirileri arasındaki ilişkiyi incelemede kullanılan bir yöntem olan olay analizi dünyada ve Türkiye'de, araştırmacılar tarafından çok çeşitli olayların irdelenmesinde kullanılmıştır. Özellikle firma açıklamaları üzerine yoğunlaşan çalışmaların yanı sıra politik seçimler, terör saldırıları, askeri operasyonları vb. olayları ele alan çok sayıda çalışmaya rastlamak mümkündür. Bu bölümde bu çalışmalardan bazılarına yer verilmiştir. 
Pantzalis vd. (2000) 1974- 1995 yılları arasında 33 farklı ülkenin politik seçimlerinin, pay senedi getirileri üzerindeki etkisini araştırmışlardır. Yazarlar, seçimlerden önceki iki haftalık dönemde pozitif anormal getirilerin elde edildiğini ileri sürmüşlerdir. Öte yandan İspanya'daki politik seçimlerin 1976-2008 yılları arasında pay senedi piyasaları üzerindeki etkilerini inceleyen Furio \& Pardo (2010), seçim sonuçlarına göre anormal getirilerin oluşmadığını savunmaktadır.

Evrim Mandacı (2003) çalışmasında yatırımcıların seçim tarihi etrafındaki günlerde önemli fiyat hareketleri beklediklerinden hareketle, 1991-2002 yılları arasında yapılan dört genel seçimin İMKB-100 endeksi getirisine etkisi olay analizi ile incelenmiştir. Yazar genel olarak seçim tarihlerinin etrafında incelenen günlerin çoğunda, pay senedi getirilerinde istatistiksel anlamlılığa sahip anormal bir getirinin gerçekleşmediği sonucuna ulaşmıştır. Buna karşın 1988-2011 yılları arasında Türkiye'de yapılan politik seçimler ve referandumlar ile pay senedi piyasaları arasındaki ilişkiyi inceleyen Ada vd. (2013) politik seçimlerin öncesinde ve sonrasında, İMKB 100 endeksinde anormal getiriler elde edildiğini savunmaktadırlar.

Gasbarro vd. (2004) sendikasyon kredisi anlaşmalarını olay olarak ele almış ve hesaplanan anormal getirilerin istatistiki olarak pozitif yönlü ve anlamlı olduğunu tespit etmişlerdir.

Moeller vd. (2005), şirket birleşmelerini ve devralmalarını olay analizi ile incelemiş ve satın alan firmanın pay senetlerinde pozitif veya negatif anormal getirilerin ortaya çıkabileceğini ileri sürmüşlerdir. Buna karşın Campa \& Hernando (2006), finans sektöründe gerçekleşen birleşme ve devralmaların sadece pozitif kümülatif aşırı getiriyle sonuçlandığını savunmuştur.

Chi \& Tang (2007), 1980-2005 yılları arasında Tayvan'da, iflas etmek üzere olan firmaların yeniden yapılanma duyurularının kendi pay senetlerini nasıl etkilediğini araştırmış ve çalışma sonucunda, elde edilen anormal getirilerin istatistiksel olarak anlamlı olduğunu tespit etmişlerdir.

11 Eylül saldırısı, 2002 Bali, 2004 Madrid ve 2005 Londra terör saldırılarının etkilerini olay analizi ile inceleyen Cam (2007), belirlenen olayların Teknoloji, Donanım ve Ekipman endeksi dışında kalan ABD endüstrileri üzerinde anlamlı bir etkisinin olmadığı sonucuna ulaşmıştır.

Aygören \& Uyar (2007) çalışmalarında denetim görüşlerinin pay senedi getirileri üzerindeki etkisini araştırmayı hedeflemişlerdir. Bu amaçla İMKB'de işlem gören 101 adet şirketin 2004 ve 2005 yıllarına ait denetim raporlarında açıklanan görüşlerini olay çalışması yöntemine göre değerlendirilmiş İMKB'nin yarı güçlü formda etkin olmadığı sonucuna ulaşmışlardır.

Sakarya (2011) çalışmasında şirketlerin derecelendirme notunun ilanı ile pay senedi getirileri arasındaki ilişkiyi incelenmiştir. Çalışma sonucunda iyi bir kurumsal yönetim derecelendirme notunun ilanı ile pay senedi getirisi arasında pozitif bir ilişkinin olduğunu tespit etmiştir. Yazar ayrıca piyasanın yarı güçlü formda etkin olmadığını ileri sürmüştür. Kurumsal Yönetim ilkelerine uyum notu ile pay senedi getirileri arasındaki ilişkiyi irdeleyen bir diğer çalışmada Aksu \& Aytekin (2015), 2009 yılında endeksin yarı güçlü formda etkin olmadığını, 2014 yılında ise endeksin etkinliğe yaklaşmış olduğunu savunmaktadırlar. 
Babacan \& Özer (2013) şirketlerin gönüllü açıklamalarını ele almışlar ve İMKB 100 endeksinde yer alan firmaların gönüllü açıklamalarının, pay senedi getirilerini etkilediğini tespit etmişlerdir.

Bozkurt vd. (2015) ise finansal tablo ilanlarının hisse getirileri üzerindeki etkisini analiz ettikleri çalışmalarında, yatırımcıların, finansal tabloların kamuoyuna açıklanmasının öncesinde ve sonrasında anormal getiriler elde ettiğini ve Türkiye sermaye piyasalarının henüz yarı etkin formda bir piyasa olmadığı sonuçlarına ulaşmışlardır.

Enflasyon açıklamalarındaki sürprizlerin, pay senedi piyasasında fiyatlanıp fiyatlanmadığını belirlemeyi amaçlayan Belen \& Gümrah (2016) anormal getirilerin mevcut olduğu fakat sistematik bir şekilde seyretmediğini tespit etmişlerdir. Yazarlar ayrıca belirli olayların pay senedi getirileri üzerindeki etkisini inceleyen olay çalışmalarının yanı sıra, varyansları üzerindeki etkileri de araştırılan çalışmalarda bulunduğunu da belirtmişlerdir.

Kaya vd. (2017) çalışmalarında 15 Temmuz darbe girişiminin BİST 30 ve 100 endeksleri üzerindeki etkisini olay analiz ile incelemişlerdir ve bazı yatırımcıların darbe girişiminin uluslararası alanda olumlu karşılanacağı beklentisi ile olay öncesinde pozisyon aldıklarını ileri sürmüşlerdir.

\section{Araştırmanın Yöntemi}

Bu çalışmada, coğrafikonumu, ekonomik ve siyasi istikrarı sonucu bölgesel ve uluslararası alandaki güç unsurları arasında yer alan Türkiye'nin finansal piyasalarının etkinliğinin test edilmesi amaçlanmıştır. Bu amaç doğrultusunda, milli gücün aktörlerinden olan ekonomik, siyasi ve askeri olayların piyasalara yönelik etkisini, Türkiye'de son zamanlarda yaşanan güç odaklı olaylar ekseninde Borsa İstanbul'da (BIST) incelenmiştir. BİST 100 Endeksinde yer alan şirketlerin pay senedi getirileri ile Türkiye'de meydana gelen önemli askeri, siyasi ve ekonomik olaylar arasındaki ilişki «Olay Çalışması» yöntemi ile analiz edilmiştir. Bir başka ifadeyle, Türkiye'de meydana gelen önemli askeri, siyasi ve ekonomik olaylar öncesi ve sonrasında pay senetlerinden anormal getirilerin elde edilip edilmediği araştırılmıştır.

Türkiye'de meydana gelen önemli olaylar kapsamında; Askeri güç unsuruna ilişkin 15 Temmuz Darbe Girişimi ve Fırat Kalkanı Operasyonu, Siyasi güç unsuruna ilişkin olarak ABD ile yaşanan Vize Krizi ve Anayasa Değişikliği Referandumu ele alınmıştır. Ekonomik güç unsuruna ilişkin ise Rusya'nın Türkiye'ye karşı almış olduğu yaptırım kararları ve Varlık Fonunun kurulması belirlenmiştir. Bu olaylardan darbe girişimi, vize krizi ve ekonomik yaptırımların pay senetleri getirileri üzerinde olumsuz etkisi olacağı, Fırat kalkanı operasyonu, Anayasa Değişikliği referandumu ve varlık fonunun kurulmasının ise olumu bir etkiye sahip olacağ 1 varsayılmıştır.

Piyasa etkinliğinin ölçülmesinde de olay çalışması yönteminden sıklıkla yararlanılmaktadır. Bu sebeple çalışmanın amacına ulaşmak için analize tabi tutulacak verilerde Olay Çalışması (Event Study) yöntemi kullanılmıştır. Söz konusu yöntem piyasada bir olay meydana geldiğinde piyasanın meydana gelen olaya verdiği anormal tepkiyi ölçmek amacıyla kullanılan bir yöntemdir. Etkin piyasalar hipotezi çerçevesinde yarı kuvvetli formda etkin olan piyasalarda, pay senetlerinin piyasaya yeni gelen bir habere yönelik reaksiyonunun yüksek 
olması beklenmemektedir. Yarı etkin formda faaliyet gösteren piyasalarda yatırımcılar elde ettikleri haberleri kullanarak anormal getiriler elde edemeyeceklerdir.

Olay çalışması ile ilgili olarak tek bir modelden söz etmek mümkün olmamaktadır. Fakat çoğunlukla olay çalışmasında dört adımdan söz edilebilir. (Eppli \& Tu, 2005:120). Bu adımlar; Olayın tanımlanması, Olay penceresinin tanımlanması (event window), Olayın etkilerinin değerlendirilmesi ve modelin kurulup test edilerek sonuçların değerlendirilmesi aşamalarıdır.

Araştırma yapılan olayın olduğu an " $t_{0}$ " Olay Anı olarak ele alınmaktadır. Olay penceresi olarak ele alınacak sürenin olay anından ne kadar öncesi ve sonrasını kapsayacağına yönelik bir görüş birliği bulunmamaktadır (Mazgit, 2013). Olay penceresi olarak ele alınacak süre ele alınan olaya ve araştırmacıya göre değişkenlik göstermekle birlikte genellikle 10 gün öncesi ve 10 gün sonrası verilerle hareket edildiği gözlemlenmektedir.

$\mathrm{Bu}$ çalışmada da incelemeye konu olan olaylar ve olay penceresi olarak ele alınan tarihler Tablo 1'de sunulmuştur.

Tablo 1: Araştırmaya Kapsamında Ele Alınan Olaylar ve Tarihleri

\begin{tabular}{cccc}
\hline Güç Unsuru & Olay & Olay Anı & Olay Penceresi \\
\hline \multirow{2}{*}{ Askeri } & 15 Temmuz Darbe Girişimi & 15.07 .2016 & $28.06 .2016-29.07 .2016$ \\
\cline { 2 - 4 } & Firat Kalkanı Harekâtı & 24.08 .2016 & $10.08 .2016-08.09 .2016$ \\
\hline \multirow{2}{*}{ Siyasi } & $\begin{array}{c}\text { Anayasa Değişikliği } \\
\text { Referandumu }\end{array}$ & 14.04 .2017 & $31.03 .2017-28.04 .2017$ \\
\cline { 2 - 4 } & ABD Vize Krizi & 06.10 .2017 & $22.09 .2017-20.10 .2017$ \\
\hline \multirow{2}{*}{ Ekonomik } & Rus Ekonomik Yaptırımları & 01.12 .2015 & $17.11 .2015-15.12 .2015$ \\
\cline { 2 - 4 } & Varlık Fonu Oluşturulması & 26.08 .2016 & $12.08 .2016-16.09 .2016$ \\
\hline
\end{tabular}

Türkiye'de meydana gelen siyasi, askeri ve ekonomik olayların Türkiye finansal piyasalarına etkisinin olup olmadığının araştırıldı $\breve{g}_{1}$ bu çalışmada olay penceresi olarak ( $\mathrm{t}+$ 10, $\mathrm{t}$ - 10) dönemi alınmıştır. Çalışmada kullanılan veri seti Borsa İstanbul resmi internet adresinden temin edilmiştir. Çalışmada Türkiye' de meydana gelen olayların finansal piyasalara etkisinin olup olmadığı, söz konusu olayın meydana geldiği anda ve sonrasında ele alınan pay senetlerinden anormal bir getiri sağlanıp sağlanmadığının tespiti ile test edilecektir.

Piyasalara gelen haberlerin pay senedi fiyatlarına yansıyıp yansımadığının test edilmesi için kullanılan yöntemlerden biri olan Olay Çalışmasında olay günü öncesi ve sonrasındaki değerler yardımıyla hesaplanan Ortalama Anormal Getiri (AAR) ve Kümülatif Anormal Getiri (CAAR) istatistiklerinden yararlanılmaktadır. Ortalama Anormal Getiri (AAR) ve Kümülatif Anormal Getiri (CAAR) üç aşamalı bir yol ile hesaplanabilmektedir (Serra, 2002:5).

1.Aşama: Endeksteki her bir şirketinin her bir günü için, fiili getiri oranları ile pazar getiri oranı arasındaki fark alınmak suretiyle, Anormal Getiri (AR) hesaplanmıştır.

Normal getiri olarak ifade edilen olay tarihindeki toplam pazar getirisinden fazla veya düşük olan getiriler Anormal Getiriler (Abnormal Return - AR) olarak adlandırılır (Seans 
\& Sandoval, 2005:310-315). Anormal getiriler aşağıdaki formül yardımıyla hesaplanabilir (MacKinlay 1997:15; Lyon vd., 1999: 172);

\section{Anormal Getiri = Fiili Getiri Oranı - Pazar Getiri Oranı}

$$
A R_{i t}=R_{i t}-R_{m t}
$$

Denklemde yer alan; " $R_{i t}$ ” ilgili pay senedinin " $t_{0}$ ” günündeki fiili getirisini, " $R_{m t}$ " ise " $t_{0}$ " günündeki pazar getirisini ifade etmektedir. Ele alınan pay senedine ilişkin fiili getiri " $R_{i t}$ ” ve Pazar getirisi $R_{m t}$ aşağıdaki denklemler yardımıyla hesaplanabilmektedir.

$$
R_{i t}=\left(D+P_{i t}-P_{i t-1}\right) / P_{i t-1}
$$

Denklemdeki " $P_{i t}$ " "i” pay senedinin “t” zamanındaki kapanış fiyatını, " $P_{i t-1}$ ” "t-1" günündeki kapanış fiyatını, D ise pay senedine ilgili gün için ödenen kar payını göstermektedir.

$$
R_{m t}=\left(I_{t}-I_{t-1}\right) / I_{t-1}
$$

Denklemdeki " $R_{m t}$ ” ilgili pay senedinin pazar getirisini, “ $I_{t}$ ” BİST 100 endeksinin "t” günündeki kapanış değerini, “ $I_{t-1}$ ” ise BİST 100 endeksinin "t-1" günündeki kapanış değerini göstermektedir. Bu çalışmada Pazar Getiri Oranı'nın hesaplanmasında BİST 100 Endeksi günlük kapanış değerleri kullanılmış ve pazar getirileri yukarıdaki eşitlik yardımı ile hesaplanmiştır.

2.Aşama: Elde edilen her bir anormal getiri, uygulamaya konu olan şirket sayısına bölünerek, Ortalama Anormal Getiri (AAR) hesaplanmıştır.

$$
A A R_{i t}=\sum_{i=1}^{N}\left(\frac{1}{N}\right) A A R_{i t}
$$

3.Aşama: Hesaplanan ortalama anormal getiriler, sırasıyla birbirleriyle toplanarak, Kümülatif Anormal Getiriler (CAAR) hesaplanmıştır. (Sakarya, 2011).

$$
C A R_{i t}=\sum_{i=1}^{N} \cdot A A R_{i t}
$$

$\mathrm{Bu}$ aşamadan sonra hesaplanan Ortalama ve Kümülatif Anormal Getiriler yardımıyla piyasanın etkinliği sınanacaktır. Ĕger hesaplanan Kümülatif Anormal Getiriler (CAAR) istatistiksel olarak 0'dan farklı ise ilgili olayın piyasada duyulması söz konusu pay senedini etkilemiştir ve o pay senedinden/piyasadan anormal getiri elde edilmesi mümkün olacaktır. Eğer elde edilen CAAR değerleri istatistiksel olarak sıfıra eşit ise, bu durumda da ilgili haberlerin piyasada duyulmasının pay senedi fiyatına etkisinin olmadığı ve piyasanın yarı güçlü formda etkin olduğu sonucuna ulaşılabilecektir.

\section{Özetle;}

CAAR $\neq 0$ ise piyasa yarı güçlü forma etkin değildir. Böyle bir durumda yatırımcılar kamuya açıklanan duyurulardan ve piyasaya ulaşan haberlerden faydalanarak anormal getiriler elde edebilecektir. Ele alınan piyasanın geneli için de Etkin Piyasalar Hipotezi kapsamında Yarı Güçlü formda etkin olmadığ kabul edilecektir. 
CAAR $=0$ veya 0 `a çok yakın ise piyasa yarı güçlü formda etkindir. Böyle bir durumda yatırımcılar kamuya açıklanan duyurulardan ve piyasaya ulaşan haberlerden faydalanarak anormal getiriler elde edemeyecektir. Ele alınan piyasanın geneli için de Etkin Piyasalar Hipotezi kapsamında Yarı Güçlü formda etkin olduğu savunulacaktır.

\section{Bulgular}

Askeri, siyasi ve ekonomik güç unsurlarına ilişkin ele alınan olaylara ilişkin t-10 ile t+10 günleri arasındaki ortalama aşırı getiriler Tablo 2'de sunulmuştur. Bu tabloya göre askeri güç unsuru olarak ele alınan olaylardan darbe girişimi olayı için en yüksek getiri t+5 gününde gerçekleşirken Fırat Kalkanı Operasyonu için $t_{0}$ günündeki görülmüştür. En düşük getiri ise darbe girişimi olayında $t+1$ gününde, Fırat Kalkanı Operasyonunda $t+6$ gününde gerçekleşmiştir. Darbe girişimi olayı için hesaplanan pozitif getirilerden $t-5, t+5, t+6, t+7$ ve $\mathrm{t}+10$ günlerindeki getirilere ilişkin $\mathrm{t}$ istatistiği anlamlı iken Fırat Kalkanı Operasyonu için hesaplanan pozitif getirilerden yalnızca $\mathrm{t}-2$ ve $\mathrm{t}+3$ günlerindeki getiriler istatistiksel olarak anlamlıdır. Siyasi olaylar açısından Tablo 2 incelendiğinde, vize krizinde en düşük ve en yüksek getirinin sırasıyla t-9 ve t-7 günlerinde gerçekleştiği görülmektedir. Anayasa değişikliği referandumu için ise en düşük getiri t-4 gününde ve $t+1$ günlerinde gerçekleşmiştir. Vize krizi olayı için t- 8 ve t-4 günleri arasında hesaplanan pozitif getirilere ilişkin $t$ istatistiği anlamlı iken Anayasa değişikliği referandumu için hesaplanan pozitif getirilerden t-9, t-8, t-7 ve t-6 günlerinin yanı sıra $t+1$ ve $t+3$ günlerindeki getirilerde istatistiksel olarak anlamlıdır.

Ekonomik güç unsurlarına ilişkin ele alınan olaylara ilişkin t-10 ile t+10 günleri arasındaki ortalama aşırı getiriler irdelendiğinde, ekonomik yaptırım olayı için en yüksek getiri t-10 en düşük getiri t-10 gününde gerçekleşmiştir. Varlık fonunun kurulması olayı için ise en düşük getiri $t+4$ 'de gerçekleşirken en yüksek getiri $t+9$ da gerçekleşmiştir. Ekonomik yaptırım olayı için hesaplanan pozitif getirilerden $\mathrm{t}-4, \mathrm{t}-1$ ve $\mathrm{t}+1$ günlerindeki getirilere ilişkin $\mathrm{t}$ istatistiği anlamlı iken, varlık fonunun kurulması olayı için hesaplanan pozitif getirilerden $t-4, t+1, t+9$ ve $t+3$ günlerindeki getiriler istatistiksel olarak anlamlıdır.

Ayrıca gerçekleşen olayın yatırımcılar tarafından olumlu algılanmasının olay günü (t) aşırı getirilerin pozitif, olumsuz algılanmasının negatif etki oluşturması beklenebilmektedir (Bulut \& Eyyüpoğlu, 2016). Olay günü ve t+1'de olumsuz olarak algılanan darbe girişiminden sonra negatif, olumlu olarak algılanan Fırat Kalkanı operasyonundan sonra pozitif aşırı getirilerin ortaya çıktığı görülmektedir. Benzer şekilde olumsuz bir olay olarak ele alınan vize krizinde $t_{0}$ ve $t+1$ günlerinde negatif, olumlu bir olay olarak ele alınan Anayasa değişikliği referandumunda $t+1$ gününde pozitif aşırı getiriler gerçekleşmiştir. Buna karşın ekonomik güç unsurları olarak ele alınan olaylardan olumsuz olarak algılanan ekonomik yaptırım ve olumlu olarak algılanan varlık fonu olayları $\mathrm{t}_{0}$ gününde negatif, $\mathrm{t}+1$ gününde pozitif aşırı getiri ile sonuçlanmıştır. 


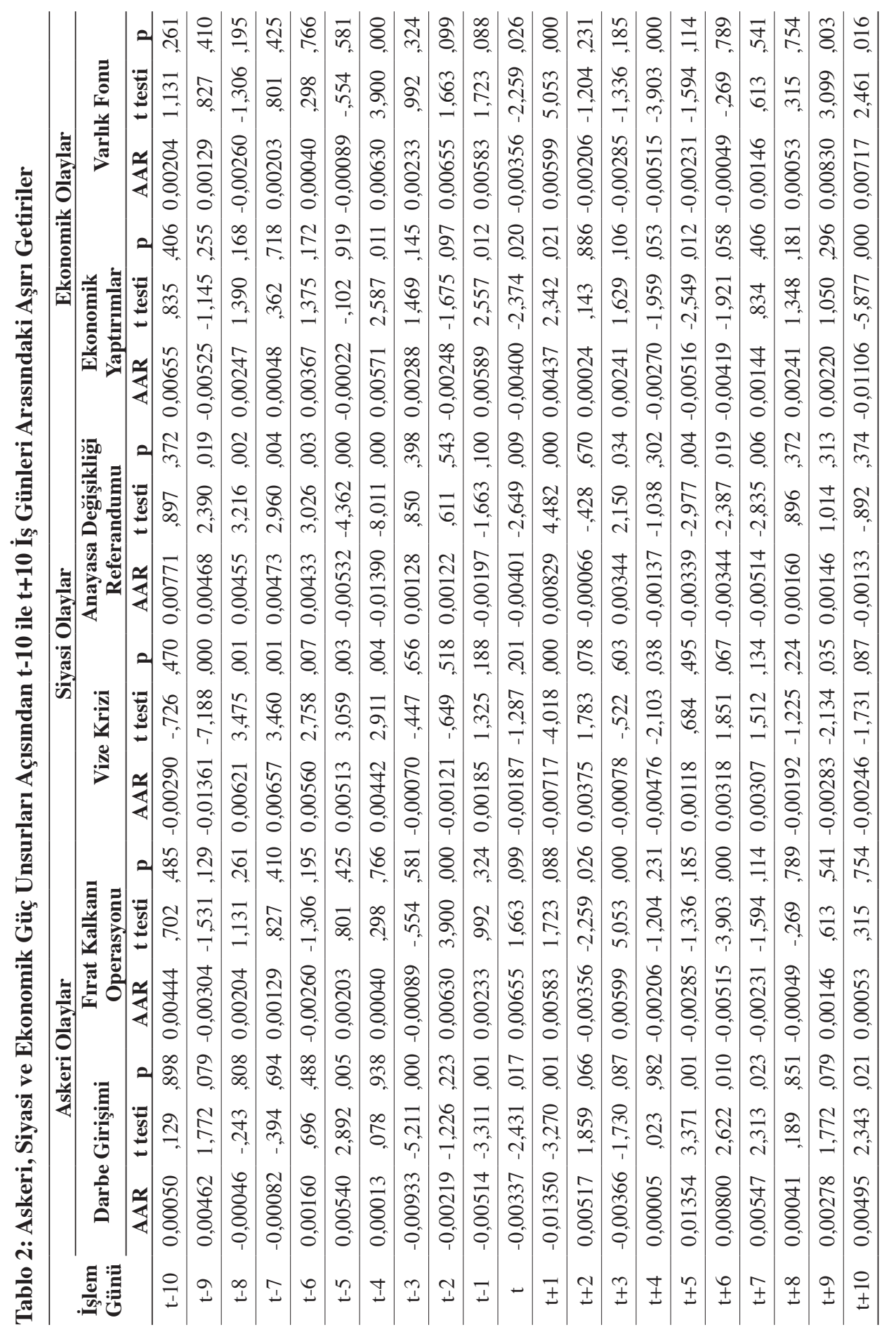


Çalışma kapsamında incelenen olaylara ilişkin t-10 ile t+10 iş günleri arasında hesaplanan kümülatif aşırı getiriler Tablo 3'de sunulmuştur.

Tablo 3: Güç Unsurları Açısından t-10 ile t+10 İş Günleri Arasındaki Kümülatif Aşırı Getiriler

\begin{tabular}{ccccccc}
\hline & \multicolumn{2}{c}{ Askeri Olaylar } & \multicolumn{2}{c}{ Siyasi Olaylar } & \multicolumn{2}{c}{ Ekonomik Olaylar } \\
\hline \multirow{2}{*}{$\begin{array}{c}\text { İslem } \\
\text { Günleri }\end{array}$} & $\begin{array}{c}\text { Darbe } \\
\text { Girişimi }\end{array}$ & $\begin{array}{c}\text { Frrat } \\
\text { Kalkanı }\end{array}$ & Vize Krizi & Referandum & $\begin{array}{c}\text { Ekonomik } \\
\text { Yaptırımlar }\end{array}$ & $\begin{array}{c}\text { Varlı } \\
\text { Fonu }\end{array}$ \\
\cline { 2 - 7 } & CAAR & CAAR & CAAR & CAAR & CAAR & CAAR \\
\hline t-10 & 0,00050 & 0,00444 & $-0,00290$ & 0,00771 & 0,00655 & 0,00204 \\
\hline t-9 & 0,00512 & 0,00140 & $-0,01651$ & 0,01239 & 0,00131 & 0,00334 \\
\hline t-8 & 0,00467 & 0,00344 & $-0,01030$ & 0,01694 & 0,00378 & 0,00073 \\
\hline t-7 & 0,00385 & 0,00474 & $-0,00374$ & 0,02167 & 0,00426 & 0,00276 \\
\hline t-6 & 0,00545 & 0,00213 & 0,00187 & 0,02600 & 0,00792 & 0,00316 \\
\hline t-5 & 0,01085 & 0,00416 & 0,00700 & 0,02067 & 0,00770 & 0,00228 \\
\hline t-4 & 0,01098 & 0,00456 & 0,01141 & 0,00677 & 0,01341 & 0,00857 \\
\hline t-3 & 0,00165 & 0,00368 & 0,01071 & 0,00805 & 0,01629 & 0,01090 \\
\hline t-2 & $-0,00055$ & 0,00998 & 0,00951 & 0,00928 & 0,01382 & 0,01745 \\
\hline t-1 & $-0,00569$ & 0,01231 & 0,01136 & 0,00731 & 0,01970 & 0,02328 \\
\hline t & $-0,00906$ & 0,01885 & 0,00949 & 0,00330 & 0,01571 & 0,01972 \\
\hline t+1 & $-0,02256$ & 0,02468 & 0,00232 & 0,01158 & 0,02007 & 0,02571 \\
\hline t+2 & $-0,01739$ & 0,02112 & 0,00606 & 0,01092 & 0,02031 & 0,02365 \\
\hline t+3 & $-0,02104$ & 0,02711 & 0,00529 & 0,01436 & 0,02272 & 0,02079 \\
\hline t+4 & $-0,02099$ & 0,02505 & 0,00053 & 0,01300 & 0,02002 & 0,01565 \\
\hline t+5 & $-0,00745$ & 0,02220 & 0,00171 & 0,00961 & 0,01486 & 0,01334 \\
\hline t+6 & 0,00055 & 0,01705 & 0,00488 & 0,00617 & 0,01067 & 0,01285 \\
\hline t+7 & 0,00602 & 0,01474 & 0,00796 & 0,00103 & 0,01211 & 0,01431 \\
\hline t+8 & 0,00643 & 0,01425 & 0,00603 & 0,00263 & 0,01211 & 0,01484 \\
\hline t+9 & 0,00921 & 0,01571 & 0,00321 & 0,00409 & 0,01430 & 0,02314 \\
\hline t+10 & 0,01416 & 0,01624 & 0,00075 & 0,00276 & 0,00324 & 0,03031 \\
\hline & & & & & & \\
\hline
\end{tabular}

Tablo 3'de Güç unsurları açısından t-10 ile t+10 iş günleri arasındaki kümülatif aşırı getiriler sunulmuştur. Fırat Kalkanı Operasyonu, Vize Krizi ve Ekonomik Yaptırımlar olaylarında t-9 gününde, varlık fonunun kurulmasında t-8 gününde en düşük kümülatif aşırı getiriler görülürken, darbe girişiminde olay gününden bir gün sonra, başkanlık referandumunda olay gününden yedi gün sonra en düşük kümülatif aşırı getirilerin gerçekleştiği görülmektedir. Fırat Kalkanı Operasyonu ve Ekonomik Yaptırımlar olaylarında t+3 gününde, darbe girişiminde ve varlık fonunun kurulmasında t+10 gününde en yüksek kümülatif aşırı getiriler hesaplanmıştır. 
Vize krizi ve başkanlık referandumu olaylarında en yüksek kümülatif aşırı getiriler sırasıyla t-4 ve t-6 günlerine aittir.

Olay penceresi olarak ele alınacak sürenin olay anından ne kadar öncesi ve sonrasını kapsayacağına yönelik bir görüş birliği bulunmamaktadır. Bu nedenle farklı olay aralıkları ele alınarak bu olaylara ilişkin olarak kümülatif aşırı getiriler hesaplanmış ve bu değerlere ilişkin t-testleri yapılmıştır.

Tablo 4: Belirli Olay Aralıklarında CAAR Değerlerine İlişkin t Testi Analizi

\begin{tabular}{|c|c|c|c|c|c|c|}
\hline \multirow{3}{*}{$\begin{array}{c}\text { CAARs } \\
\text { Olay Aralığı }\end{array}$} & \multicolumn{6}{|c|}{ Askeri Güç Unsuru } \\
\hline & \multicolumn{3}{|c|}{ Darbe Girişimi } & \multicolumn{3}{|c|}{ Fırat Kalkanı } \\
\hline & CAAR & t değ. & $\mathbf{p}$ & CAAR & t değ. & $\mathbf{p}$ \\
\hline$(-1,+1)$ & $-0,022014$ & $-2,306$ & ,148 & 0,014708 & 2,416 & ,137 \\
\hline$(-3,+3)$ & $-0,032020$ & $-5,845$ & ,001 & 0,022542 & 3,828 & ,009 \\
\hline$(-5,+5)$ & $-0,012902$ & $-3,470$ & ,006 & 0,020061 & 4,985 &, 001 \\
\hline$(-10,+10)$ & 0,014160 &,- 491 & 629 & 0,016240 & 6,902 &, 000 \\
\hline$(-10,0)$ & $-0,009059$ & 1,158 & ,274 & 0,018853 & 3,160 & ,010 \\
\hline$(-5,0)$ & $-0,019909$ & $-1,206$ & ,282 & 0,014692 & 2,769 & ,039 \\
\hline$(-3,0)$ & $-0,016668$ & $-5,918$ & 010 & 0,007741 & 2,117 &, 125 \\
\hline$(0,+3)$ & $-0,015353$ & $-3,916$ &, 030 & 0,014802 & 5,795 &, 010 \\
\hline$(0,+5)$ & $-0,001760$ & $-4,002$ & 010 & 0,009891 & 8,860 & ,000 \\
\hline$(0,+10)$ & 0,019854 & 010 & ,992 & 0,003935 & 5,417 & ,000 \\
\hline \multirow{3}{*}{$\begin{array}{c}\text { CAARs } \\
\text { Olay Aralığı }\end{array}$} & \multicolumn{6}{|c|}{ Siyasi Olaylar } \\
\hline & \multicolumn{3}{|c|}{ Vize Krizi } & \multicolumn{3}{|c|}{ Referandum } \\
\hline & CAAR & t değ. & p & CAAR & t değ. & $\mathbf{p}$ \\
\hline$(-1,+1)$ & $-0,007188$ &,- 649 & ,583 & 0,002308 &,- 785 & 514 \\
\hline$(-3,+3)$ & $-0,006126$ & $-2,859$ & ,029 & 0,007591 & 1,857 &, 113 \\
\hline$(-5,+5)$ & $-0,000159$ & 4,132 & ,002 & $-0,016390$ & $-11,24$ &, 000 \\
\hline$(-10,+10)$ & 0,000750 & 2,051 &, 054 & 0,002760 & 7,040 &, 000 \\
\hline$(-10,0)$ & 0,009491 & ,869 & 405 & 0,003298 & 4,482 &, 001 \\
\hline$(-5,0)$ & 0,002493 & 11,852 & ,000 & $-0,017374$ & $-6,896$ & ,001 \\
\hline$(-3,0)$ & $-0,000054$ & $-2,468$ & ,090 & 0,000535 & 160 & ,883 \\
\hline$(0,+3)$ & $-0,006072$ & $-3,780$ &, 032 & 0,007056 & 1,155 &, 332 \\
\hline$(0,+5)$ & $-0,009654$ & $-5,222$ & ,003 & 0,002298 & 1,993 & ,103 \\
\hline$(0,+10)$ & $-0,010608$ & $-7,873$ & ,000 & $-0,004550$ &,- 059 & ,954 \\
\hline
\end{tabular}


Tablo 4 devam

\begin{tabular}{|c|c|c|c|c|c|c|}
\hline \multirow{3}{*}{$\begin{array}{c}\text { CAARs } \\
\text { Olay Aralığı }\end{array}$} & \multicolumn{6}{|c|}{ Ekonomik Olaylar } \\
\hline & \multicolumn{3}{|c|}{ Ekonomik Yaptırımlar } & \multicolumn{3}{|c|}{ Varlık Fonu } \\
\hline & CAAR & t değ. & $\mathbf{p}$ & CAAR & t değ. & $\mathbf{p}$ \\
\hline$(-1,+1)$ & 0,006257 & 3,345 & ,079 & 0,008254 & 3,138 & ,088 \\
\hline$(-3,+3)$ & 0,009310 & 4,165 & ,006 & 0,012221 & 6,239 & 001 \\
\hline$(-5,+5)$ & 0,006942 & 6,829 &, 000 & 0,010174 & 6,134 & ,000 \\
\hline$(-10,+10)$ & 0,003240 & 8,970 &, 000 & 0,030310 & 7,017 & ,000 \\
\hline$(-10,0)$ & 0,015706 & 4,271 &, 002 & 0,019718 & 3,118 & ,011 \\
\hline$(-5,0)$ & 0,008006 & 4,002 & 010 & 0,017442 & 3,295 &, 022 \\
\hline$(-3,0)$ & 0,006292 & 2,414 & ,095 & 0,014708 & 3,557 & 038 \\
\hline$(0,+3)$ & 0,003018 &,- 102 & ,919 & $-0,002488$ &,- 601 &, 590 \\
\hline$(0,+5)$ & $-0,004842$ &,- 612 &, 568 & $-0,009945$ & $-1,818$ & ,129 \\
\hline$(0,+10)$ & $-0,014057$ & $-2,613$ & ,026 & 0,007032 & $-2,184$ &, 054 \\
\hline
\end{tabular}

Tablo 4 incelendiğinde vize krizi ve ekonomik yaptırım olaylarında en düşük CAAR değeri $(-10,0)$ olay penceresinde gerçekleşirken, en yüksek CAAR değerinin ise $(0,+10)$ olay penceresinde gerçekleştiği görülmektedir. Fırat Kalkanı Operasyonu ve Başkanlık Referandum için en yüksek CAAR değeri $(-3,+3)$ olay penceresinde hesaplanmıştır. Araştırma kapsamında ele alınan hiçbir olayda $(-1,+1),(-5,+5)$ ve $(0,+3)$ olay pencerelerinde en yüksek veya en düşük CAAR değeri görülmemiştir. $(0,+10)$ olay penceresinde Fırat Kalkanı Operasyonu, Vize krizi ve ekonomik yaptırım olayları için en düşük CAAR değeri hesaplanmışken, darbe girişimi olayı için ise en yüksek CAAR değeri hesaplanmıştır.

Güç unsurunun belirleyicileri olarak ele alınan tüm olaylar ile ilişkili belirli olay aralıkları için hesaplanan CAAR'lara ilişkin t testi istatistik değerleri gösterilmiştir. Buna göre, belirlenen bütün olaylarda, $(-5,+5)$ olay aralıklarında hesaplanan CAAR'lar istatistiksel açıdan anlamlı iken $(-1,+1)$ olay aralığında hesaplanan hiçbir CAAR değeri istatistiksel olarak anlamlı değildir. $(-3,+3)$ olay aralığında Başkanlık Referandumu olayı hariç, $(-5,0)$ olay aralığında ise darbe girişimi hariç tüm olaylar için hesaplanan CAAR değerleri istatistiki açıdan anlamlıdır. $(-10,+10)$ ve $(-10,0)$ olay aralıklarında ekonomik yaptırım, Fırat kalkanı operasyonu, varlık fonu ve başkanlık referandumu olaylarında hesaplanan CAAR değerleri istatistiki olarak pozitif yönlü ve anlamlıdır. $(-1,+1)$ olay aralığ 1 hariç olay öncesi veya sonrasında kümülatif aşırı getirilerin olması piyasanın yarı güçlü formda etkin olmadığını göstermektedir.

\section{Sonuçlar}

$\mathrm{Bu}$ çalışmada coğrafi konumu, ekonomik ve siyasi istikrarı sonucu, bölgesel ve uluslararası alandaki güç unsurları arasında yer alan Türkiye'nin finansal piyasalarının etkinliğinin test edilmesi amaçlanmıştır. Türkiye'nin ekonomik ve finansal gücü, askeri, siyasi ve ekonomik güç unsurları çerçevesinde olay analizi yöntemi ile incelenmiştir. Ayrıca incelenen olaylar çerçevesinde finansal piyasaların etkinlik derecesini gösteren Etkin Piyasalar 
Hipotezinin de sınanması gerçekleştirilmiştir. Gücün askeri, siyasi ve ekonomik unsurları çerçevesinde Türkiye'de son yıllarda meydana gelen önemli olaylardan askeri olay olarak; 15 Temmuz Darbe Girişimi ve Fırat Kalkanı Harekâtı, ekonomik olay olarak; Rusya'nın Türkiye'ye Uyguladığı Ekonomik Yaptırımlar ve Varlık Fonunun Oluşturulması, siyasi olay olarak; Başkanlık Referandumu ve ABD Vize Krizi ele alınmıştır. Bu olaylardan darbe girişimi, vize krizi ve ekonomik yaptırımların pay senetleri getirileri üzerinde olumsuz etkisi olacağı, Firat kalkanı operasyonu, Anayasa referandumu ve varlık fonunun kurulmasının ise olumlu bir etkiye sahip olacağı varsayılmıştır.

Çalışmada olay penceresi olarak $(t+10, t-10)$ dönemi alınmıştır. Ayrıca farklı olay pencereleri de belirlenerek sonuçlar karşılaştırılmıştır. Normal getiri olarak ifade edilen olay tarihindeki toplam pazar getirisinden fazla veya düşük olan Anormal Getiriler hesaplanmış, elde edilen her bir anormal getirilerin toplamı, uygulamaya konu olan şirket sayısına bölünerek, Ortalama Anormal Getiri (AAR) hesaplanmıştır. Daha sonra anormal getiriler, sırasıyla birbirleriyle toplanarak, Kümülatif Anormal Getiriler (CAAR) elde edilmiştir. CAAR değerleri istatistiksel olarak sıfıra eşit ise, bu durumda piyasanın yarı güçlü formda etkin olduğuna karar verilmiştir.

Çalışma sonucunda, güç unsuru açısından olumlu etkiye sahip olacağı varsayılan Fırat Kalkanı Operasyonu için $\mathrm{t}_{0}$ gününde, Anayasa referandumu için $\mathrm{t}+1$ gününde, Varlık fonu için ise t+9 gününde en yüksek normal üstü getiriler elde edilmiştir. Buradan hareketle üç olayın da, olay gününden sonra olumlu olarak algılandığını ve pozitif normal üstü getirilere neden olduğu ileri sürülebilir.

Kümülatif anormal getiriler incelendiğinde, Anayasa referandumu hariç tüm olaylarda en yüksek kümülatif getirinin en düşük kümülatif getiriden sonra gerçekleştiği görülmektedir. Başka bir ifade ile elde edilen kümülatif getiriler genel olarak artan bir seyir göstermektedir. Buna tek istisna olarak gösterilecek Anayasa referandumu olayında, piyasa oyuncularının Anaysa referandumunun kabul edileceği beklentisi ile işlem yaptıkları, beklentileri gerçekleştikten sonra pozisyon değiştirdikleri ileri sürülebilir. Benzer durum Anayasa referandumu olay penceresinde normal üstü getiriler içinde geçerlidir.

Normalüstü getirilere ilişkin $t$ istatistik değerlerinin incelenmesi sonucu $(-1,+1)$ olay penceresinde tüm olaylarda piyasaların yarı güçlü formda etkin olduğu söylenebilir. Öte yandan $(-5,+5)$ olay penceresinde ise tüm olaylar için elde edilen kümülatif normalüstü getiriler sıfırdan farklıdır. $(-10,+10)$ olay penceresinde askeri güç (darbe girişimi) ve siyasi güç (vize krizi) açısından piyasaların yarı güçlü formda etkinliğinden bahsedilebilir fakat ekonomik güç açısından aynı şeyleri söylemek mümkün değildir. Ekonomik yaptırımlar açısından ise $(-3,0)$, $(0,+3)$ ve $(0,+5)$ olay pencerelerinden piyasa etkinliğinden söz edilebilir.

Çalışma sonuçları değerlendirildiğinde Borsa İstanbul BİST 100 Endeksinin yarı güçlü formda etkin olmadığı sonucu literatürde yer alan Sakarya (2011) ve Bozkurt vd. (2015) çalışmaları ile benzerlik göstermektedir. Öte yandan Borsa İstanbul BİST 100 Endeksinin özellikle milli reflekslerin ön plana çıkacağı darbe girişimi, vize krizi gibi olaylarda tepkisel işlemler nedeni ile piyasanın dengeye ulaştığı savunulabilir. Her ne kadar tam anlamı ile etkinlikten söz edilemezse de Türkiye'nin finans piyasalarının gücünün arttığı ileri sürülebilir. 
Çalışma milli güç unsurları ile sınırlıdır. Bundan sonra yapılacak çalışmalarda araştırmacılara, gücün farklı tanımlarından hareketle belirlenen olayları dikkate alan çalışmaların yapılması önerilebilir.

\section{Kaynakça}

Ada, S. S., Bolak, M., \& Süer, Ö. (2013). Politik seçimler, referandumlar ve hisse senedi getirileri: İMKB örneği. Finans Politik \& Ekonomik Yorumlar, 50(579), 23-40.

Aksu, M., \& Aytekin, S. (2015). Kurumsal yönetim ilkelerine uyum notu ile hisse senedi getirisi ilişkisi: BIST kurumsal yönetim endeksi (XKURY) üzerine bir uygulama. Gümüşhane Üniversitesi Sosyal Bilimler Elektronik Dergisi, 6(13), 201-219.

Aygören H., \& Uyar, S. (2007). İstanbul Menkul Kıymetler Borsası'nda (İMKB) denetim görüşlerinin hisse senedi getirileri üzerindeki etkisi. IMKB Dergisi, 9(36), 31-51.

Babacan, B., \& Özer, G. (2013). Şirketlerin gönüllü açıklamalarının hisse senedi getirileri üzerine etkileri. Yönetim ve Ekonomi, 20(2), 91-104.

Barber, B. R. (1996). Jihad vs. McWorld. How globalism and tribalism are reshaping the World. New York: Ballantine Books.

Belen, M., \& Gümrah, Ü. (2016). Türkiye'de hisse senedi piyasasının enflasyon açıklamalarındaki sürprizlere tepkisi. İnsan ve Toplum Bilimleri Araştırmaları Dergisi Ekonomi \& İsletme Özel Sayısı, 5(3), 428 - 441.

Bozkurt, İ., Öksüz, S., \& Karakuş, R. (2015). Finansal tablo ilanlarının hisse getirileri üzerindeki etkisi: BİST'de ampirik bir uygulama. Maliye Finans Yazıları, 103, 113-140.

Bulut, H. İ., \& Eyüboğlu, K. (2016). Şirketlere özgü haberlerin hisse performansına etkisi: Bist-30 şirketleri örneği. Uluslararası İktisadi ve İdari İncelemeler Dergisi, 16, 113-138.

Cam, M. A. (2007). The impact of terrorist attacks on financial markets (Doctor of Philosophy PhD). RMIT University, Economics, Finance and Marketing.

Campa, J. M., \& Ignacio, H. (2006). M\&As performance in the European financial industry. Journal of Banking and Finance, 30 (12), 3367 - 3397.

Chi, L. C., \& Tang, T. C. (2007). Impact of reorganization announcements on distressed-stock returns. Economic Modelling, 24 (5), 749-767.

Dahl, R. (1957). The concept of power. Behavioral Sciences, 2, 201-215.

Eppli, M. J., \& Charles C. T. (2005). An event study analysis of mall renovation and expanion. Journal of Shopping Center Research, 12 (2), 117-130.

Erhan, Ç. (2012). Dış politikanın yürütülmesinde askerî gücün önemi. Türkiye Gazetesi. Erişim Tarihi: 14.08.2012, http://www.turkiyegazetesi.com.tr/yazarlar/prof-dr-cagri-erhan/545332.aspx

Evrim Mandacı, P. (2003). IMKB' de genel seçimler öncesi ve sonrasında anormal fiyat hareketleri. IMKB Dergisi, 7 (27), 1-16.

Furıo, D., \& Pardo, A. (2012). Partisan politics theory and stock market performance: Evidence for Spain. Spanish Journal of Finance and Accounting, 41(155), 371- 392.

Gasbarro, D., Song L. K., Schwebach, R. G., \& Zumwalt, J. K. (2004). Syndicated loan announcements and borrower value. The Journal of Financial Research, 27(1), 133-141.

Kaya, İ., Keskin Köylü, M., \& Günay, B. (2017). 15 Temmuz darbe girişiminin BİST 30/100 endeksleri üzerine etkisinin olay çalışması (event study) yöntemi ile analizi. Uluslararası İktisadi ve İdari Bilimler Dergisi, 3(2), 54-67. 
Lukes, S. (1974). Power: A radical view. London: MacMillan Press.

Lyon, J. D., Barber, B. M., \& Tsai, C. L. (1999). Improved methods for tests of long-run abnormal stock returns. The Journal of Finance, 54 (1), 165-201.

MacKinlay, A. C. (1997). Event studies in economics and finance. Journal of Economic Literature, 35 (March, 1997), 13-39.

Mazgit, İ. (2013). Endeks kapsamında olmanın hisse senedi getirilerine etkisi: BIST temettü 25 endeksi üzerine bir uygulama. Sosyo Ekonomi Dergisi, 2, 225 - 264.

Milli Güvenlik Kurulu Genel Sekreterliği (MGK). Hakkımızda. Erişim Tarihi: 07.02.2018, https://www. mgk.gov.tr/index.php/kurumsal/hakkimizda

Moeller, S. B., Frederik, P., Schlingemann, R., \& Stulz, M. (2005). Wealth destruction on a massive scale? A study of acquiring firm returns in the recent merger wave. Journal of Finance, 60(2), 757-782.

Nye, J. (1990). Soft power. Foreign Policy, 80, 153-171.

Pantzalis, C., Stangeland, D. A., \& Turtle, H. J. (2000). Political elections and the resolution of uncertainty. The International Evidence Journal of Banking \& Finance, 24(10), 1575-1604.

Sağlam, Z. (2012). Güç kavramı ve Ortadoğu'da değişen dengeler üzerinden güç okuması. İnsani ve Sosyal Araştırmalar Merkezi, Araştırma Raporları. Erişim Tarihi: 07.02.2018, http://insamer.com/ wp-content/uploads/2014/02/G\%C3\%BC\%C3\%A7-kavram\%C4\%B1-ve-Ortado\%C4\%9Fudade $\%$ C4\%9Fi\%C5\%9Fen-dengeler-\%C3\%BCzerinden-g\%C3\%BC\%C3\%A7-okumas\%C4\%B1. pdf.

Sakarya, Ş. (2011). İMKB kurumsal yönetim endeksi kapsamındaki şirketlerin kurumsal yönetim derecelendirme notu ve hisse senedi getirileri arasındaki ilişkinin olay çalışması (event study) yöntemi ile analizi. ZKÜ Sosyal Bilimler Dergisi, 7(13), 147-162.

Seans, R., \& Eduardo S. (2005). Measuring security price performance using chilean daily stock returns: The event study method. Cuadernos De Economia, 42, 307-328.

Serra, A. P. (2002). Event study tests - a brief survey. Working papers da FEP, No 117, May. Erişim Tarihi:10.05.2009, http://www.fep.up.pt.

Velde, D.W. (2008). The global financial crisis and developing countries - which countries are at risk and what can be done? . Background Note, October, Overseas Development Institute. 